\title{
Preferred anatomic site for intraosseous infusion in Danish emergency departments
}

\author{
Rune Molin ${ }^{1^{*}}$, Peter Hallas ${ }^{2}$, Mikkel Brabrand ${ }^{3}$, Thomas Andersen Schmidt ${ }^{1}$ \\ From Danish Society for Emergency Medicine: Research Symposium 2010 \\ Roskilde, Denmark. 20-21 May 2010
}

\section{Background}

Intraosseous infusion (IOI) is recommended when intravenous access cannot be readily established in resuscitation. There has been debate as to whether which anatomic site should be preferred for IOI. Although success and flow rates in e.g. proximal tibia compared with proximal humerus are not significant different some stress that the tibia should be first choice for IOI because of easily identifiable landmarks. We have as part of a project on IOI use in Danish emergency departments (EDs) assessed the preferred anatomic site for IOI. We hope to promote a debate concerning first choice insertion site for IOI.

\section{Methods}

Links to an online questionnaire were e-mailed to the Chief of Staff of the twenty emergency departments currently established in Denmark; non-responders were contacted by telephone. The questionnaire focused on the use of IOI in the emergency department including training, equipment, and attitudes. Results concerning preferred anatomical site are presented her.

\section{Results}

Overall response rate was $95 \%$. Seventy four per cent of Danish emergency department have intraosseous devices. The preferred injection sites were the tibia $(84 \%, \mathrm{n}=16)$, humerus $(10 \%, \mathrm{n}=2)$ the medial malleolus $(10 \%, \mathrm{n}=2)$ and $5 \%(\mathrm{n}=1)$ had no preference.

\section{Conclusion}

The tibia is the preferred anatomical site for IOI in Danish EDs. We believe that the preference for tibia as

\footnotetext{
* Correspondence: molin@dadlnet.dk

'Department of Emergency Medicine, Holbæk Sygehus, Holbæk, Denmark
} Full list of author information is available at the end of the article first choice for IOI may reflect experiences with children were tibia this is the typical insertion site.

\section{Author details}

'Department of Emergency Medicine, Holbæk Sygehus, Holbæk, Denmark. ${ }^{2}$ Department of Anaesthesiology, JMC, Rigshospitalet, Copenhagen, Denmark. ${ }^{3}$ Department of Medicine, Sydvestjysk Sygehus, Esbjerg, Demark.

Published: 17 September 2010

\section{doi:10.1186/1757-7241-18-S1-P26}

Cite this article as: Molin et al:: Preferred anatomic site for intraosseous infusion in Danish emergency departments. Scandinavian Journal of Trauma, Resuscitation and Emergency Medicine 2010 18(Suppl 1):P26.
Submit your next manuscript to BioMed Central and take full advantage of:

- Convenient online submission

- Thorough peer review

- No space constraints or color figure charges

- Immediate publication on acceptance

- Inclusion in PubMed, CAS, Scopus and Google Scholar

- Research which is freely available for redistribution

Submit your manuscript at www.biomedcentral.com/submit
C Biomed Central 